\title{
Synthesis and characterization of redox active cyrhetrene- triazole click products
}

\author{
David P. Day, Thomas Dann, Robin J. Blagg, Gregory G. Wildgoose*
}

\section{School of Chemistry, University of East Anglia, Norwich, NR4 7TJ, United Kingdom}

KEYWORDS: Cyclopentadienylrhenium tricarbonyl, click chemistry, triazole, electrochemistry.

\begin{abstract}
We report the synthesis and characterization of two new cyclopentadienyl tricarbonyl rhenium(I) (cyrhetrene) complexes modified with a 1,4-disubstituted 1,2,3-triazole moiety. The two compounds, $\left(\eta^{5}-\left[4-\right.\right.$ phenyltriazol-1-yl]cyclopentadienyl) tricarbonyl rhenium(I), and $\left(\eta^{5}-[4-(4-\right.$ aminophenyl)triazol-1-yl]cyclopentadienyl) tricarbonyl rhenium(I), were structurally characterized using ${ }^{1} \mathrm{H}$ and ${ }^{13} \mathrm{C}$ NMR, ATR-IR spectroscopy, UV-vis spectroscopy, mass spectrometry and $X$-ray crystallography where appropriate. The electrochemical behaviour of these two cyrhetrene-triazole complexes was explored using cyclic voltammetry, whereupon we observed that irreversible oxidation of the pendant 4-substiuted-triazole moiety occurs before any electron transfer at the metal centre. This redox behaviour is in stark contrast to that of the analogous manganese(I) cymantrene-triazole derivatives, recently reported by our group.
\end{abstract}




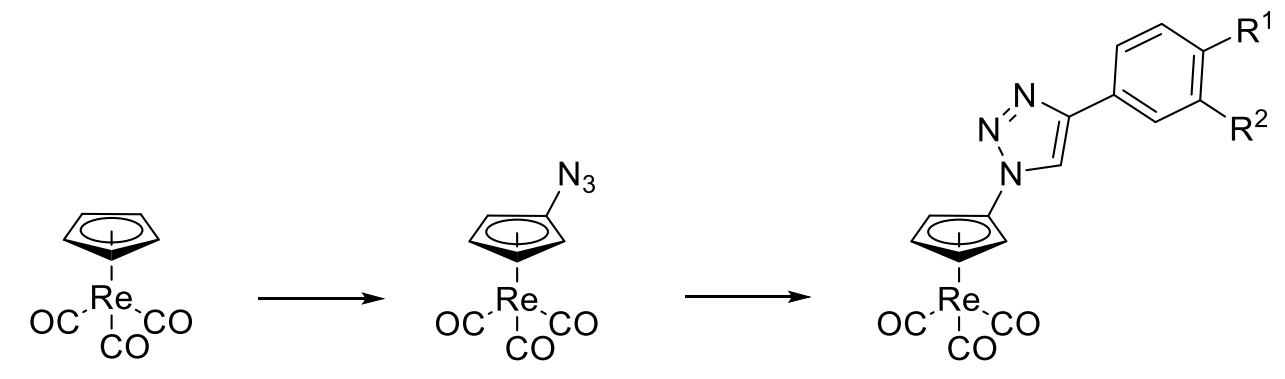

\section{Introduction}

The chemistry of half-sandwich complexes has been of recent interest in the literature, ${ }^{1}$ with complexes such as cyclopentadienyl tricarbonyl manganese(I) illustrating versatility with its introduction into a wide array of research areas, including exploiting the photo-labile carbonyl ligands, ${ }^{2}$ modification of the cyclopentadienyl moiety to generate new organometallic species, ${ }^{3}$ and even incorporating the cymantrene moiety into drug molecules. ${ }^{4}$

Cyclopentadienyl tricarbonyl rhenium (I), $\mathbf{1}$, is the next commercially available complex in the group 7 series (with the technetium analogue being radioactive), ${ }^{5}$ that we wished to focus our attention upon. The applications of cyclopentadienyl rhenium(I) tricarbonyl, $\mathbf{1}$, have recently been reported in a wide array of research areas, including examples that have shown the photolysis of $\mathrm{CO}$ ligands allowing the coordination of new ligands $\left(\mathrm{CS}_{2}, \mathrm{PPh}_{3}\right),{ }^{6}$ utilizing the $\mathrm{CO}$ ligands of 1 as non-natural labels for probing protein electrostatics, ${ }^{7}$ and modification of the cyclopentadienyl moiety to allow the formation of new cyrhetrene complexes with bidentate ligands, capable of forming new palladacycles. ${ }^{8}$

Geiger has previously investigated the anodic behaviour of cyclopentadienyl tricarbonyl rhenium(I) 1, and has shown that the half-cell potential for the cyclopentadienyl tricarbonyl rhenium(I) redox couple ${ }^{+1 / 2}$ is $+1.16 \mathrm{~V} v$ s the ferrocene/ferricenium couple. ${ }^{9}$ Interestingly, this 
oxidation is only partly reversible in $\mathrm{CH}_{2} \mathrm{Cl}_{2}$ (with $[n-\mathrm{Bu} 4 \mathrm{~N}]\left[\mathrm{B}\left(\mathrm{C}_{6} \mathrm{~F}_{5}\right)_{4}\right]$ as the supporting electrolyte), ${ }^{10}$ due to the formation of the dimer, $\left[\operatorname{Re}_{2} \mathrm{Cp}_{2}(\mathrm{CO})_{6}\right]^{2+}$, which shows an irreversible cathodic wave around $c a 0.55 \mathrm{~V} v s$ the ferrocene/ferricenium couple. Furthermore, the use of $\left[\operatorname{ReCp}(\mathrm{CO})_{3}\right]^{+}, \mathbf{1}^{+}$, as a strong one-electron oxidant proved to be an excellent electron-transfer mediator in the case of coupling unactivated olefin substrates. ${ }^{11}$

We herein report the synthesis and structural modification of cyclopentadienyl tricarbonyl rhenium(I) (cyrhetrene) complexes modified with a 1,4-disubstituted 1,2,3-triazole moiety via the copper-catalysed variant of the Huisgen 1,3-dipolar cycloaddition. ${ }^{12}$ The copper catalysed azide-alkyne "click" reaction (CuAAC) has been extensively reviewed, and the use of this methodology would adhere to stringent criteria as set by Nobel laureate, Barry Sharpless. ${ }^{13}$ Previous relevant examples of 'click' reactions within the coordination chemistry of metal complexes include the formation of various new transition-metal coordination complexes incorporating 2-pyridyl-1,2,3-triazole ligands as shown by Crowley and Schubert, ${ }^{14,15}$ Gladysz's synthesis of permetalated rhenium-platinum alkyne-azide 'click' cycloadducts, ${ }^{3}$ and Sarkar's incorporation of tripodal-triazole ligands into various transition-metal complexes. ${ }^{16}$ Molina has reported click reactions applied to organometallic sandwich complexes such as ferrocene, ${ }^{17}$ whilst the work conducted by Astruc has shown dendrimers can be modified with metallocenes and organometallics via a click chemistry reaction. ${ }^{18}$

In contrast to the behaviour of $\mathbf{1}$, and the manganese(I) cymantrene-triazole derivatives reported previously by our group, ${ }^{19}$ the two new cyrhetrene-triazole complexes reported herein are found to exhibit redox active behaviour of the triazole ligand moiety that prevents them acting as metal-based electron-transfer mediators. 


\section{Results and Discussion}

\section{Synthesis and structural characterization of 4-substituted cyrhetrene-triazole complexes}

Following the procedure reported by Gladysz and co-workers, we report the synthesis of $\mathbf{2}$ as an off-white solid (after purification via flash column chromatography) in good yield \{Scheme 1, (i)-(ii) \}. Confirmation of the structure of $\mathbf{2}$ was provided by ${ }^{1} \mathrm{H},{ }^{13} \mathrm{C}$ NMR and IR spectroscopy $\left\{\text { SI Fig. } 2 \& 5 b,\left(v \mathrm{~N}=\mathrm{N} \text { azide } / \mathrm{cm}^{-1}\right) 2124\right\}^{3}$

Our first attempt at the copper-catalysed azide/alkyne cycloaddition of $\mathbf{3}$ was achieved using the conditions we have previously reported for the manganese variant of cyrhetrene $\{$ Scheme 1 , (iii) $\} \cdot{ }^{3,19,20}$ Reassuringly, the transformation of $\mathbf{2}$ into $\mathbf{3}$ was complete in 8 hours under these mild conditions; purification of $\mathbf{3}$ via silica gel flash column chromatography afforded $\mathbf{3}$ as a white crystalline solid in good yield and high purity (Scheme 1).

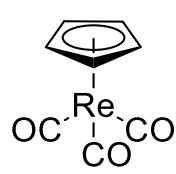

1
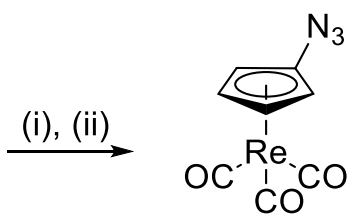

2

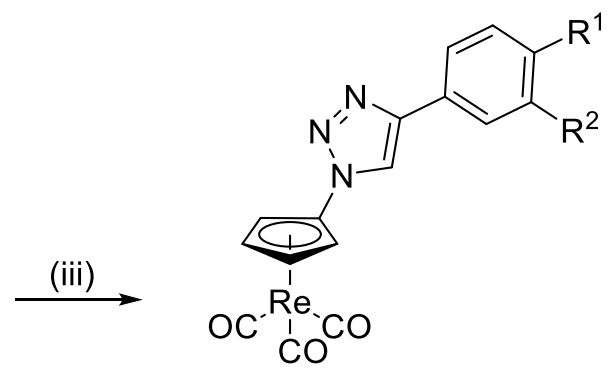

$$
\begin{aligned}
& \text { 3; } R^{1}, R^{2}=H, 56 \% \\
& \text { 4; } R^{1}=N_{2}, R^{2}=H, 59 \%
\end{aligned}
$$

Scheme 1. Reagents and conditions: (i) 1 (1 equivalent), $n$-BuLi (1 equivalent), THF, $-78^{\circ} \mathrm{C}, 2$ h; (ii) $p$-toluenesulfonylazide ( 1 equivalent), THF, $-78{ }^{\circ} \mathrm{C}-\mathrm{rt}, 14 \mathrm{~h}$. (iii) 2 (1 equivalent), phenylacetylene ( 1 equivalent for 3), or 4-ethynylaniline (1 equivalent for 4), $\mathrm{Cu}(\mathrm{OAc})_{2} \cdot \mathrm{H}_{2} \mathrm{O}$ (0.1 equivalent), $\mathrm{CH}_{3} \mathrm{CN}, 8 \mathrm{~h}$. 
The ${ }^{1} \mathrm{H}$ NMR spectrum of $\mathbf{3}$ allows us to assign the key areas of the complex, confirming that our product was indeed the desired ( $\eta^{5}$-[4-phenyltriazol-1-yl]cyclopentadienyl tricarbonyl rhenium(I) product. We observe a characteristic splitting of the five protons in the cyclopentadienyl ligand observed as a singlet in $\mathbf{1}$, into two equivalent triplets integrating to two protons each for the cyclopentadienyl protons of complex 3 (chemical shifts in the range $\delta$ 5.6$6.5 \mathrm{ppm}$ ), formed by the introduction of a single triazole moiety. ${ }^{1} \mathrm{H}$ COSY NMR experiments have shown the aromatic protons of the phenyl substituent attached to the triazole moiety can couple to one another around the region of $\delta 7.3-8.0 \mathrm{ppm}$. The proton at the 5-position of the triazole moiety is observed as a characteristic singlet at $\delta 8.86 \mathrm{ppm}$ (see Supporting Information SI Fig. 3).

The UV-vis spectra of the parent molecule, $\left[\mathrm{CpRe}(\mathrm{CO})_{3}\right] \mathbf{1}$, can be directly compared with clickproduct 3, and we show that in both cases, we observe MLCT bands around the region of 250$280 \mathrm{~nm}$ (see Supporting Information SI, Fig. 6). ${ }^{21}$

The infra-red spectral data recorded for compounds 1-4, with band assignments, are tabulated below \{Table 1, See SI Figs. 5 (a)-(d) for IR spectra of compounds 1-4 \}.

Table 1. $\left(v / \mathrm{cm}^{-1}\right)$ Bands for complexes 1-4

\begin{tabular}{|c|c|c|c|}
\hline \multirow{2}{*}{ Complex } & \multicolumn{2}{|c|}{$v(\mathrm{C} \equiv \mathrm{O}) / \mathrm{cm}^{-1}$} & $v(\mathrm{C}=\mathrm{C})$ (triazole) \\
\cline { 2 - 3 } & sym & asym & \\
\hline $\mathbf{1}$ & 2014 & 1888 & $\mathrm{~cm}$ \\
\hline $\mathbf{2}$ & 2019 & 1907 & $\mathrm{n} / \mathrm{a}$ \\
\hline & & & $\mathrm{n} / \mathrm{a}$ \\
\hline
\end{tabular}




\begin{tabular}{|c|c|c|c|}
\hline 3 & 2021 & $\begin{array}{c}1949,1927, \\
1907^{[\mathrm{a}]}\end{array}$ & 1530 \\
\hline $\mathbf{4}$ & 2025 & $\begin{array}{c}1939,1908, \\
1897^{[\mathrm{a}]}\end{array}$ & $1621,1565,1498$ \\
\hline
\end{tabular}

${ }^{[a]}$ An extra band is observed in the asymmetric region for samples run in the solid state as a result of hindered rotation about the Re-Cp centroid and a subsequent descent in symmetry.

In the case of compounds 3 and $\mathbf{4}$ we observe both symmetric and asymmetric $(\mathrm{C} \equiv \mathrm{O})$ stretches at $\sim 2020 \mathrm{~cm}^{-1}$ and $1900-1950 \mathrm{~cm}^{-1}$ respectively, ${ }^{9,22}$ in addition to characteristic $\mathrm{C}=\mathrm{C}$ stretches of the triazole group in the region of $1500-1600 \mathrm{~cm}^{-1} \cdot 19,23$

Single crystals of $\mathbf{3}$ were grown by diffusion of petroleum ether into a saturated $\mathrm{CH}_{2} \mathrm{Cl}_{2}$ solution of the compound at room temperature and a $X$-ray crystal structure obtained (Figure 1, bond lengths and angles detailed in tables S1 and S2). The structure is comparable to our previously reported manganese analogue ${ }^{19}$ with two molecules in the asymmetric unit related by a noncrystallographic pseudo-inversion centre. The cyclopentadienyl-triazole-phenyl rings of each molecule are approximately co-planar (the triazole ring is twisted by $c a .12^{\circ}$ from the co-planar cyclopentadienyl and phenyl rings), with the aromatic ring systems of each molecule approximately parallel, separated by $c a .3 .5 \AA$; together this suggests the possibility of not only a conjugated $\pi$-system in each molecule but also a degree of $\pi$ - $\pi$ interaction between the molecules. Compound 4 exhibits the same crystallographic behaviour as its manganese analogue, ${ }^{19}$ and resisted all our exhaustive attempts to grow single crystals suitable for $X$-ray crystallographic characterisation. 


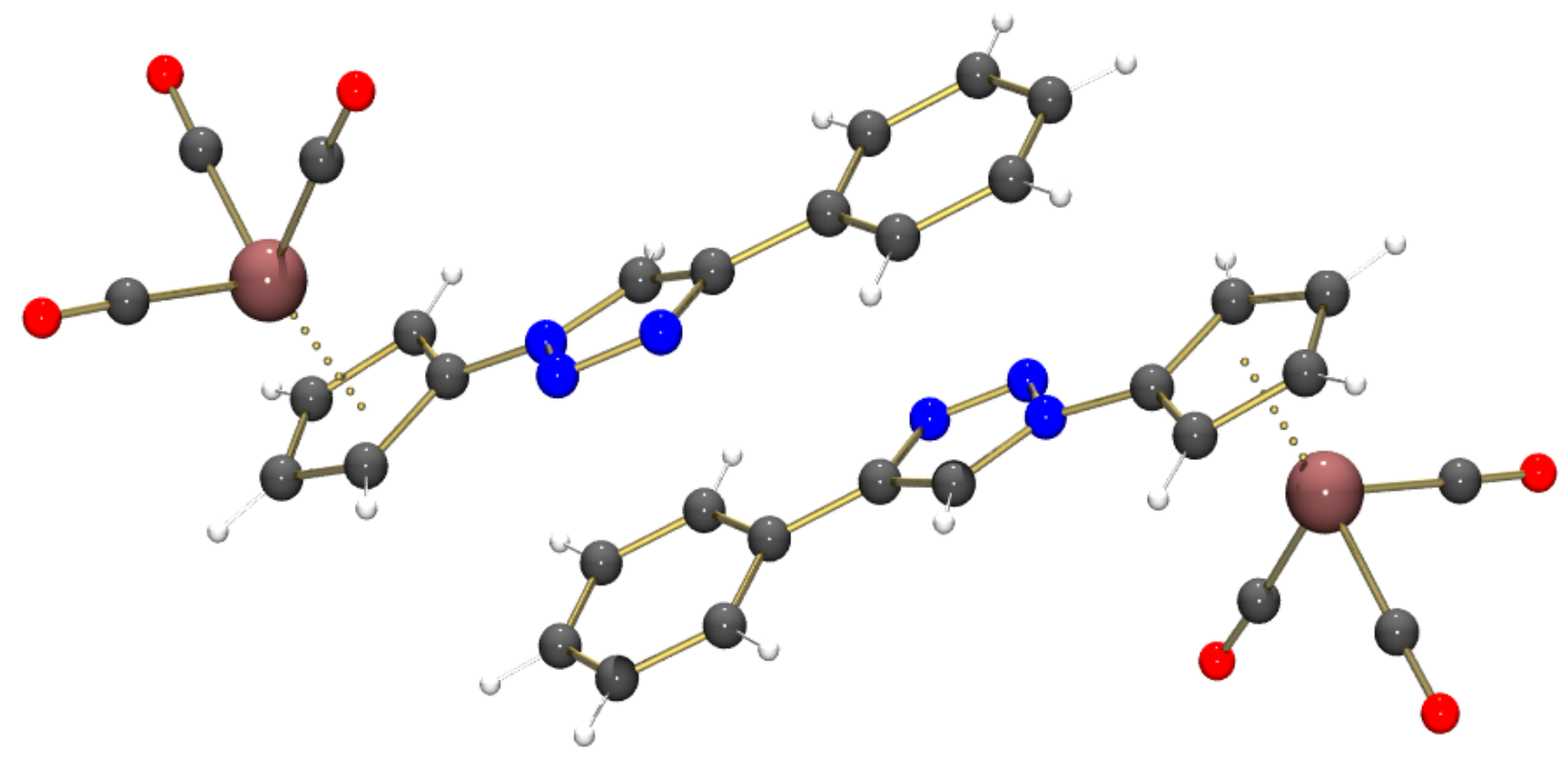

Figure 1. Molecular Structure of $\left[\mathrm{Re}(\mathrm{CO})_{3}\left(\mathrm{C}_{5} \mathrm{H}_{4}-\mathrm{N}_{3} \mathrm{C}_{2} \mathrm{H}-\mathrm{C}_{6} \mathrm{H}_{5}\right)\right] 3$.

\section{Electrochemical characterization}

We first investigated the electrochemical properties of $3(2 \mathrm{mM})$, in dichloromethane containing $0.1 \mathrm{M}\left[{ }^{n} \mathrm{Bu}_{4} \mathrm{~N}\right]\left[\mathrm{B}\left(\mathrm{C}_{6} \mathrm{~F}_{5}\right)_{4}\right]$ as supporting electrolyte, using cyclic voltammetry $(\mathrm{CV}$, Figures $2 \mathrm{a}$ and b).
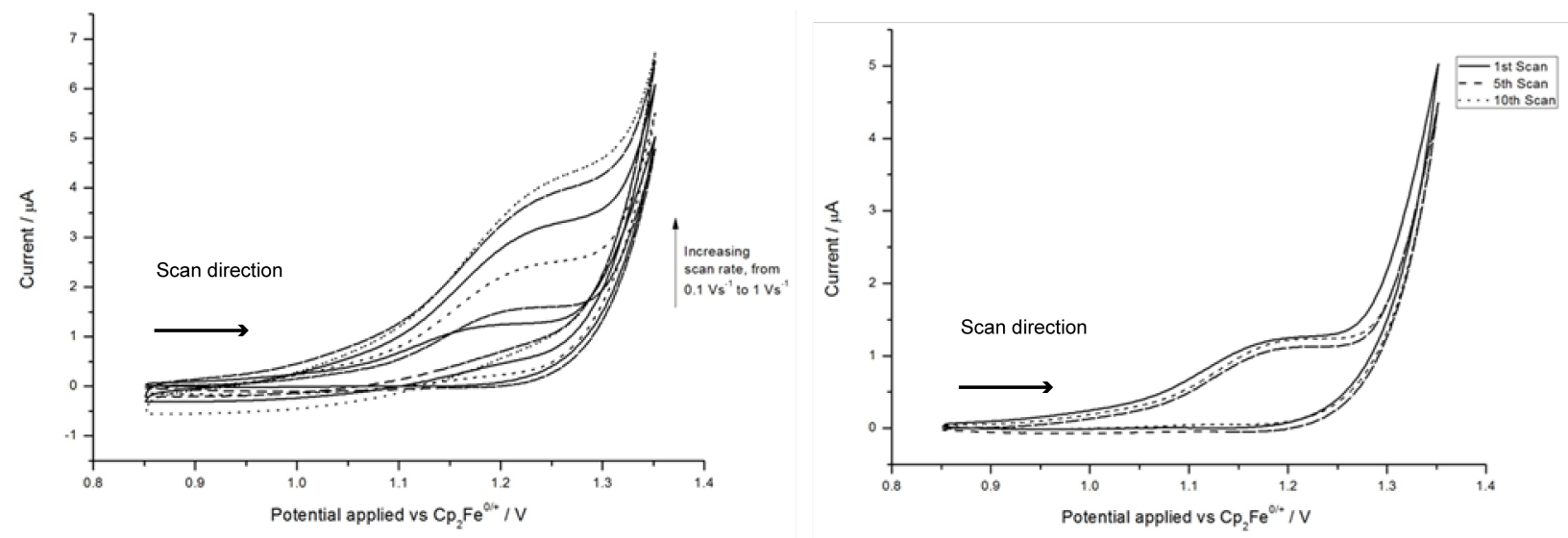

Figure 2. (a) above left; Cyclic voltammogram recorded for $2 \mathrm{mM} 3$ in $\mathrm{CH}_{2} \mathrm{Cl}_{2}(0.1 \mathrm{M}$, $\left[{ }^{n} \mathrm{Bu}_{4} \mathrm{~N}\right]\left[\mathrm{B}\left(\mathrm{C}_{6} \mathrm{~F}_{5}\right)_{4}\right]$ as electrolyte) over the oxidative region at varied scan rates. (b) above right; Cyclic voltammogram recorded for $2 \mathrm{mM}\left(\eta^{5}\right.$-[4-phenyltriazol-1-yl]cyclopentadienyl tricarbonyl 
rhenium(I) 3 in $\mathrm{CH}_{2} \mathrm{Cl}_{2}\left(0.1 \mathrm{M},\left[{ }^{n} \mathrm{Bu}_{4} \mathrm{~N}\right]\left[\mathrm{B}\left(\mathrm{C}_{6} \mathrm{~F}_{5}\right)_{4}\right]\right.$ as electrolyte) over the oxidative region at repeated scan rate of $100 \mathrm{mV} \mathrm{s}^{-1}$.

The oxidation of $\mathbf{3}$ shows only a single, irreversible oxidation wave at $c a 1.20 \mathrm{~V} v s$ ferrocene at all scan rates studied. The oxidation wave is stable over repeat voltammetric cycles at a gold macroelectrode, whilst fouling and passivation of the working electrode was observed at platinum and glassy carbon working electrodes. By comparison with the voltammetry observed for the parent cyrhetrene, $\mathbf{1},{ }^{9}$ the observed voltammetry of $\mathbf{4}$ is not characteristic of the oxidation of the rhenium metal centre, and is instead likely due to the oxidation of the pendant 4 substituted triazole moiety. ${ }^{19}$ This finding contrasts with our earlier studies of the triazolederivatised cymantrene analogue, ( $\eta^{5}$-[4-phenyltriazol-1-yl]cyclopentadienyl tricarbonyl manganese(I), where oxidation of the manganese centre occurred before any oxidation of the triazole ligand, and likely reflects the difference in the relative redox potentials of cymantrene and cyrhetrene, the latter of which is oxidised at more positive potentials. ${ }^{19}$

The voltammetric behaviour of $\mathbf{4}$ recorded under identical conditions as described above is shown in Figure 3 and Figure S7.

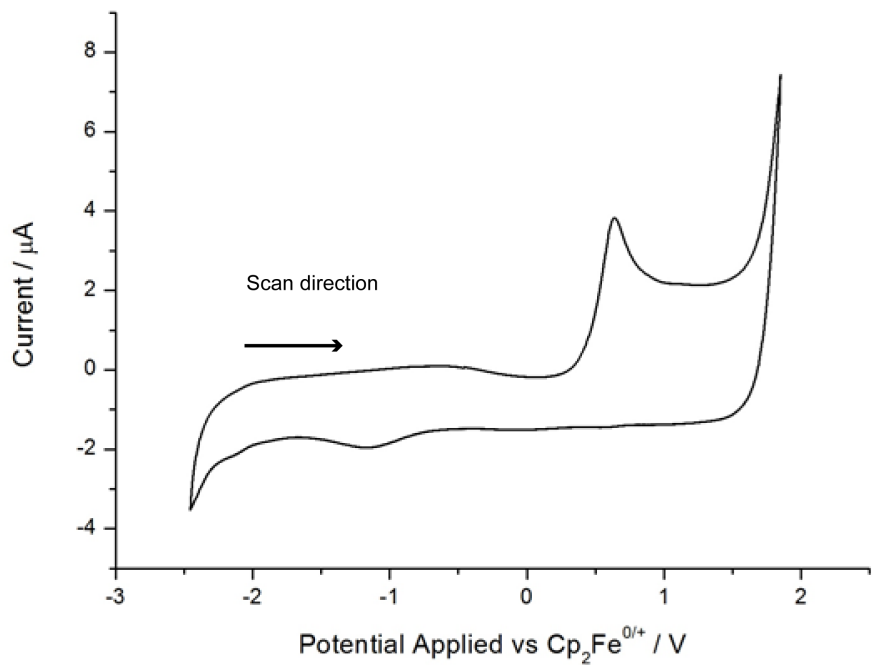

Figure 3. Cyclic voltammogram recorded for $1.4 \mathrm{mM} 4$ in $\mathrm{CH}_{2} \mathrm{Cl}_{2}\left(0.1 \mathrm{M},\left[{ }^{n} \mathrm{Bu}_{4} \mathrm{~N}\right]\left[\mathrm{B}\left(\mathrm{C}_{6} \mathrm{~F}_{5}\right)_{4}\right]\right.$ as electrolyte) over the full region at $200 \mathrm{mV} \mathrm{s}^{-1}$. 
Upon scanning in an oxidative direction an irreversible oxidation wave is observed at $c a 0.64 \mathrm{~V}$ $v s$ ferrocene. No oxidation wave corresponding to oxidation of the Re metal centre is observed beyond this first oxidation peak up to the limit of the solvent window. Instead the voltammogram exhibits a rectangular wave shape indicative of a large capacitive charging process. Upon reversing the scan direction at the limit of the solvent window a new, broad, ill-defined reduction process is observed at ca. $-1 \mathrm{~V}$ vs. ferrocene with a correspondingly broad and ill-defined associated re-oxidation wave observable on subsequent scans. The symmetric wave shape of these new features suggests a surface bound redox process. This voltammetric behaviour is characteristic of the oxidation of the pendant aniline moiety on the triazole backbone to form redox active polymeric species on the electrode surface, resulting in an increase in capacitive charging background current and fouling of the electrode surface. Again, a gold macroelectrode was found to be least susceptible to this fouling process, whilst both GCE and platinum working electrodes fouled to the extent that meaningful voltammetric data could not be recorded. Variable scan rate data (Figure S7, Supporting Information) were recorded at the gold electrode with polishing to renew the electrode surface between scans.

Once again, the observation that the 4-substituted triazole ligand moiety is oxidised before any evidence of Re metal-centred oxidation processes in $\mathbf{4}$ is the opposite of what is observed in the analogous $\quad\left(\eta^{5}-[4-(4-a m i n o p h e n y l)\right.$ triazol-1-yl]cyclopentadienyl tricarbonyl manganese(I) complex. ${ }^{19}$

\section{Conclusions}

The synthesis and structural characterization of ( $\eta^{5}$-[4-phenyltriazol-1-yl]cyclopentadienyl) tricarbonyl rhenium(I), 3, and ( $\eta^{5}$-[4-(4-aminophenyl)triazol-1-yl]cyclopentadienyl) tricarbonyl rhenium(I), 4, complexes in high purity and good yield is reported for the first time. The functionalization of group VII transition metal half-sandwich complexes with pendant triazole moieties via simple "click" chemical methods is both facile and versatile with various functional groups capable of being introduced into the 4-position of the triazole ring. The structural and spectroscopic characteristics of $\mathbf{3}$ and $\mathbf{4}$ are similar to the analogous manganese complexes recently reported by our group, ${ }^{19}$ yet, the oxidative redox behaviour of the rhenium-containing complexes is markedly different. Whereas the 4-substituted cymantrene-triazole complexes exhibit oxidation of the manganese centre to form reactive radical cationic intermediates, the 
cyrhetrene-triazole complexes $\mathbf{3}$ and $\mathbf{4}$ do not. Instead, the observed voltammetry of $\mathbf{3}$ and $\mathbf{4}$ both exhibit redox behaviour consistent with oxidation of the 4-substituted triazole ligand moiety, with no observable oxidation of the $\operatorname{Re}(\mathrm{I})$ metal centre. This redox active ligand behaviour is most pronounced for the 4-aminophenyl substituted triazole moiety in $\mathbf{4}$, but in either case, oxidation leads to the formation of ill-defined polymeric species that foul the electrode surface.

Comparison of the voltammetric behaviour of triazole-derivatised cymantrene and cyrhetrene analogues also highlights an interesting inversion of redox behaviour: during oxidation of the parent cymantrene and cyrhetrene complexes, the electrogenerated cyrhetrene radical cation shows a strong propensity to form a Re-Re bonded dimeric dication, ${ }^{9}$ whilst the cymantrenyl radical cation does not. This reflects the propensity of third row transition metals to readily form metal-metal bonds $\mathrm{cf}$ their first row counterparts. However, when the cymantrene and cyrhetrene complexes are derivatised with 4-substituted triazole moieties, it is the cymantrene-triazole complexes that exhibit evidence of dimerization during the oxidation process, whereas we observe no evidence of dimerization in the case of the analogous Re complexes 3 or 4 . Likewise, the parent cyrhetrene complex, $\mathbf{1}$, has been shown to be a potent oxidative electron-transfer mediator catalysing $\mathrm{C}-\mathrm{C}$ and $\mathrm{C}$-halide activation reactions, whilst the parent cymantrene halfsandwich complex is not catalytically active for such reactions. In contrast, the cyrhetrenetriazole derivatives, $\mathbf{3}$ and $\mathbf{4}$, show no evidence of acting as metal-based electron transfer redox mediators, whilst the cymantrene-triazole analogues may show promise for this application. This highlights the need for greater understanding of the factors influencing the electronic structure and redox behaviour of organometallic complexes during simple structural manipulation of the coordinating ligands, and forms part of our ongoing research efforts.

\section{Experimental}

General Methods. Unless stated otherwise all reagents were purchased from Sigma-Aldrich (Gillingham, UK) and used as supplied with the exception of cyclopentadienylrhenium tricarbonyl 1 (Strem Chemicals, Cambridge, UK) and 4-ethynylaniline (Fluorochem, Derbyshire, UK). $p$-toluenesulfonylazide ${ }^{24}$ and cyclopentadienylrhenium tricarbonyl azide $\mathbf{2}^{3}$ were prepared according to literature procedures. 
All reactions and manipulations were performed under an atmosphere of dry oxygen-free $\mathrm{N}_{2}$, using either standard Schlenk techniques or in a MBraun UNIlab glovebox. All solvents were dried prior to use by refluxing over an appropriate drying agent $\{\mathrm{Na} /$ benzophenone for $\mathrm{n}$ pentane, n-hexane, petroleum ether (b.p $40-60{ }^{\circ} \mathrm{C}$ ), diethyl ether and tetrahydrofuran; $\mathrm{Na}$ for toluene; $\mathrm{CaH}_{2}$ for $\mathrm{CH}_{2} \mathrm{Cl}_{2}$ and $\mathrm{MeCN}$ \}, collected by distillation and stored over 3 or $4 \AA$ molecular sieves prior to use.

${ }^{1} \mathrm{H}$ and ${ }^{13} \mathrm{C}$ NMR spectra were recorded using a Bruker Avance III spectrometer (operating frequency $500.21 \mathrm{MHz}$ for ${ }^{1} \mathrm{H}$ and $125.05 \mathrm{MHz}$ for ${ }^{13} \mathrm{C}$ ). Chemical shift values are quoted in parts per million (ppm, $\delta$ ), and coupling constants $J$ are quoted in hertz $(\mathrm{Hz})$. High resolution mass spectra (HRMS) were obtained from the service provided by the EPSRC Mass Spectrometry Service at the University of Swansea. HRMS were run on an LTQ Orbitrap XL instrument as solid samples utilizing an ASAP probe. Data were collected using APCl (ionization mode) and FTMS (FT analyzer). Elemental analyses were obtained from the service run at London Metropolitan University utilizing a Carlo Erba Flash 2000 Elemental Analyzer, configured for $\% \mathrm{CHN}$. Infrared spectra were acquired using a PerkinElmer $\mu-A T R$ Spectrum II spectrophotometer. Solid samples and liquid samples were run neat utilizing the ATR unit of the spectrometer.

Single crystals of $\mathbf{3}$ were grown by diffusion of petroleum ether into a saturated $\mathrm{CH}_{2} \mathrm{Cl}_{2}$ solution of the compound at room temperature; an appropriate crystal was selected and data collected by the EPSRC National Crystallographic Service at the University of Southampton, where the data was reduced and an absorption correction performed Using Olex $2,{ }^{25}$ the structure was solved and space group assigned with SuperFlip/EDMA ${ }^{26}$ using charge flipping, and then refined with the ShelXL (version 2014/3) ${ }^{27}$ refinement program using least squares minimisation. Two unassigned electron density peaks $\left(5.8,4.7 \mathrm{e}^{-\mathrm{A}^{-3}}\right)$ were observed in the asymmetric unit approximately $2.5 \AA$ from each rhenium centre; such peaks were previously observed for the isostructural manganese analogue ${ }^{19}$ in which case they were modelled as low occupancy (3\%) manganese atoms, however in this case it was decided to leave them unassigned since doing so does not adversely affect the molecular structure of the species of interest. 
Table 2 Crystallographic data for 3.

\begin{tabular}{|c|c|}
\hline & {$\left[\mathrm{Re}(\mathrm{CO})_{3}\left(\mathrm{C}_{5} \mathrm{H}_{4}-\mathrm{N}_{3} \mathrm{C}_{2} \mathrm{H}-\mathrm{C}_{6} \mathrm{H}_{5}\right)\right] \mathbf{3}$} \\
\hline empirical formula & $\mathrm{C}_{16} \mathrm{H}_{10} \mathrm{~N}_{3} \mathrm{O}_{3} \mathrm{Re}$ \\
\hline formula weight & 478.47 \\
\hline temperature / K & $100(2)$ \\
\hline crystal system & orthorhombic \\
\hline space group & $P$ na $2_{1}$ \\
\hline$a / \AA$ & $14.7050(10)$ \\
\hline$b / \AA$ & $5.9013(4)$ \\
\hline$c / \AA$ & $33.413(2)$ \\
\hline$\alpha /{ }^{\circ}$ & 90 \\
\hline$\beta /{ }^{\circ}$ & 90 \\
\hline$\gamma / 0$ & 90 \\
\hline volume / $\AA^{3}$ & $2899.5(3)$ \\
\hline$Z$ & 8 \\
\hline$\rho_{\text {calc }} / \mathrm{mg} \cdot \mathrm{mm}^{-3}$ & 2.192 \\
\hline$\mu / \mathrm{mm}^{-1}$ & 8.400 \\
\hline $\mathrm{F}(000)$ & 1808.0 \\
\hline crystal size $/ \mathrm{mm}^{3}$ & $0.15 \times 0.03 \times 0.005$ \\
\hline $2 \Theta$ range for data collection & 4.876 to $54.968^{\circ}$ \\
\hline index ranges & $-18 \leq h \leq 19,-6 \leq k \leq 7,-36 \leq l \leq 43$ \\
\hline reflections collected & 16200 \\
\hline independent reflections & $6075\left[\mathrm{R}_{\mathrm{int}}=0.0989, \mathrm{R}_{\text {sigma }}=0.0633\right]$ \\
\hline data / restraints / parameters & $6075 / 1 / 415$ \\
\hline goodness-of-fit on $\mathrm{F}^{2}$ & 1.060 \\
\hline final $R$ indexes $[I \geq 2 \sigma(I)]$ & $\mathrm{R}_{1}=0.0529, \mathrm{wR}_{2}=0.1315$ \\
\hline final $\mathrm{R}$ indexes [all data] & $\mathrm{R}_{1}=0.0540, \mathrm{wR}_{2}=0.1325$ \\
\hline largest diff. peak / hole / e. $\mathrm{A}^{-3}$ & $5.81 /-1.13$ \\
\hline Flack parameter & $0.504(16)$ \\
\hline
\end{tabular}

Cyclic Voltammetry (CV) was performed using a computer-controlled potentiostat (PGSTAT302N, Autolab, Utrecht, The Netherlands) with a standard three-electrode configuration. CV data were analysed using the in-built NOVA software. A silver wire (99.99\% GoodFellow, Cambridge, UK) served as the pseudo-reference electrode and was calibrated to the ferrocene/ferricenium redox couple at the beginning and end of each series of experiments as recommended by IUPAC. ${ }^{28}$ A platinum coil served as the counter electrode $(99.99 \%$ Goodfellow, Cambridge, UK). The working electrode was a gold macroelectrode (99.99\% Goodfellow, Cambridge, UK) of either $0.5 \mathrm{~mm}$ or $0.35 \mathrm{~mm}$ diameter. The working electrode was polished between experiments using successive grades of alumina slurry (1.0-0.1 micron, 
Kemmet, UK), subjected to a brief period of ultrasonication in distilled water to remove any adhered microparticles, and then placed in a drying-oven prior to use. Cyclic voltammograms were recorded in dry dichloromethane under an inert nitrogen atmosphere using an in-house design of inert atmosphere electrochemical cell maintained at $20 \pm 2{ }^{\circ} \mathrm{C}$. The cells were assembled under inert atmosphere in a nitrogen-filled glovebox (MBraun). [ $\left.{ }^{n} \mathrm{Bu} 4 \mathrm{~N}\right]\left[\mathrm{B}\left(\mathrm{C}_{6} \mathrm{~F}_{5}\right)_{4}\right]$ was prepared according to the known literature procedure, ${ }^{29}$ and used as a supporting electrolyte $(0.1 \mathrm{M})$ throughout.

$p$-Toluenesulfonylazide: ${ }^{24}$ A solution of $p$-toluenesulfonylchloride $(9.5 \mathrm{~g}, 49.7 \mathrm{mmol})$ in acetone $(25 \mathrm{~mL})$ was added to a stirred solution of sodium azide $(3.6 \mathrm{~g}, 55.4 \mathrm{mmol})$ in water $(15$ $\mathrm{mL}$ ). The solution was allowed to stir for $2 \mathrm{~h}$ at ambient temperature. The reaction mixture was concentrated under reduced pressure, the residue extracted with dichloromethane $(50 \mathrm{~mL})$ and dried over $\mathrm{MgSO}_{4}$. Removal of volatiles at reduced pressure affords a colourless oil (7.35 g, 75\%). ${ }^{1} \mathrm{H}$ NMR (500 MHz, $\mathrm{CDCl}_{3}$ ): $\delta 7.80$ (d, 2H, J = $8 \mathrm{~Hz}$ ), 7.38 (d, 2H, J = $8 \mathrm{~Hz}$ ), 2.45 (s, 3H). ${ }^{13} \mathrm{C} \mathrm{NMR}\left(125 \mathrm{MHz}, \mathrm{CDCl}_{3}\right): 146.3,135.4,130.3,127.4,21.7$

Cyclopentadienylrhenium tricarbonyl azide $2:^{3}$ To a cold $\left(-78^{\circ} \mathrm{C}\right)$ solution of cyclopentadienylrhenium tricarbonyl $1(1.0 \mathrm{~g}, 3.0 \mathrm{mmol})$ in $50 \mathrm{~mL}$ of THF was added $1.6 \mathrm{M}$ solution of $n$-BuLi in hexanes $(1.9 \mathrm{~mL}, 3.0 \mathrm{mmol})$, and the reaction mixture left to stir at $-78^{\circ} \mathrm{C}$ for $2 \mathrm{~h}$. A solution of $p$-toluenesulfonylazide $(0.6 \mathrm{~g}, 3.0 \mathrm{mmol})$ dissolved in dry THF $(50 \mathrm{~mL})$ was then added via cannula dropwise to the stirred solution over a period of 10 minutes. The resultant orange solution was allowed to warm to room temperature for $13 \mathrm{~h}$ in the dark. Removal of remaining solvents under reduced pressure afforded the thermally unstable cyclopentadienylrhenium tricarbonyl azide $\mathbf{2}$ as a crude brown solid. Purification of $\mathbf{2}$ using silica gel flash column chromatography (eluent: petroleum ether 60/40) afforded 2 as an off-white solid $\left(0.8 \mathrm{~g}, 71 \%, \mathrm{R}_{f}=0.32\right)$. ATR-FT IR $v_{\max } / \mathrm{cm}^{-1} ; 3121,2963,2125\left(v_{\mathrm{NN}}\right), 2019\left(v_{\mathrm{CO}}\right), 1907$ $\left(v_{\mathrm{CO}}\right), 1468,1282,813 .{ }^{1} \mathrm{H}$ NMR (500 MHz, $\left.\mathrm{CDCl}_{3}\right): \delta 5.23(\mathrm{t}, 2 \mathrm{H}, J=2 \mathrm{~Hz}), 5.33$ (t, $2 \mathrm{H}, J=2$ $\mathrm{Hz}$ ) (residual 1 at $5.37 \mathrm{ppm}) .{ }^{13} \mathrm{C} \mathrm{NMR}\left(125 \mathrm{MHz}, \mathrm{CDCl}_{3}\right): \delta 73.5(2 \mathrm{C}), 81.7$ (2C), $119.4(\mathrm{C}$ quat.), $193.0(\mathrm{CO})$ (residual 1 at $84.6 \mathrm{ppm}$ ). 
$\eta^{5}$-(4-phenyltriazol-1-yl)cyclopentadienyl tricarbonyl rhenium(I) $3:^{19,20}$ To a solution of cyclopentadienylrhenium tricarbonyl azide $2(0.1 \mathrm{~g}, 0.27 \mathrm{mmol})$ in acetonitrile $(10 \mathrm{~mL})$ was added phenylacetylene $(0.03 \mathrm{~g}, 0.27 \mathrm{mmol})$ and $\mathrm{Cu}(\mathrm{OAc})_{2} \cdot \mathrm{H}_{2} \mathrm{O}(0.005 \mathrm{~g}, 0.027 \mathrm{mmol})$ and stirred at ambient temperature under a nitrogen atmosphere. Reaction progress was monitored by thin layer chromatography, and upon completion solvents were removed under reduced pressure. The residue was purified directly using silica gel flash column chromatography (petroleum ether 60/40: acetone, 15:2) yielding 3 as a white crystals after slow evaporation $\left(0.072 \mathrm{~g}, 56 \%, \mathrm{R}_{f}=\right.$ 0.15). ATR-FT IR $v_{\max } / \mathrm{cm}^{-1} ; 3125,2962,2021\left(v_{\mathrm{CO}}\right), 1949\left(v_{\mathrm{CO}}\right), 1927\left(v_{\mathrm{CO}}\right), 1907\left(v_{\mathrm{CO}}\right), 1530$ $\left(v_{\mathrm{C}=\mathrm{C}}\right), 1452,1260,1088,1022,875,797 .{ }^{1} \mathrm{H}$ NMR (500 MHz, $d_{6}$-acetone) $\delta 5.78(2 \mathrm{H}, \mathrm{t}, J=2$ $\mathrm{Hz}), 6.46(2 \mathrm{H}, \mathrm{t}, J=2 \mathrm{~Hz}), 7.38(1 \mathrm{H}, \mathrm{t}, J=7 \mathrm{~Hz}), 7.47(2 \mathrm{H}, \mathrm{t}, \mathrm{O} J=7 \mathrm{~Hz}), 7.92(2 \mathrm{H}, \mathrm{d}, J=7$ $\mathrm{Hz}), 8.86(1 \mathrm{H}, \mathrm{s}) .{ }^{13} \mathrm{C} \mathrm{NMR}\left(125 \mathrm{MHz}, \mathrm{CDCl}_{3}\right): \delta 194.2(3 \mathrm{x} \mathrm{C} \equiv \mathrm{O}), 148.7,131.1,129.8(2 \mathrm{C})$, 129.3, 126.4 (2C), 120.7, 112.4, 84.2 (2C), 77.7 (2C). Anal. calcd for $\mathrm{C}_{16} \mathrm{H}_{10} \mathrm{ReN}_{3} \mathrm{O}_{3}: \mathrm{C}, 40.16$; H, 2.11; N, 8.78; Found: C, 40.27; H, 2.01; N, 8.67. HRMS (ASAP): $\left[\mathrm{C}_{16} \mathrm{H}_{10} \mathrm{ReN}_{3} \mathrm{O}_{3}+\mathrm{H}\right]^{+}$ requires 480.0353; Found $480.0346[\mathrm{M}+\mathrm{H}]^{+}$.

$\eta^{5}$-[4-(4-aminophenyl)triazol-1-yl]cyclopentadienyl tricarbonyl rhenium(I) $\quad 4:^{19,20}$ To a solution of cyclopentadienylrhenium tricarbonyl azide $2(0.15 \mathrm{~g}, 0.45 \mathrm{mmol})$ in acetonitrile (20 $\mathrm{mL})$ was added 4-ethynylaniline $(0.05 \mathrm{~g}, 0.45 \mathrm{mmol})$ and $\mathrm{Cu}(\mathrm{OAc})_{2} \cdot \mathrm{H}_{2} \mathrm{O}(0.06 \mathrm{~g}, 0.045 \mathrm{mmol})$ and stirred at ambient temperature under a nitrogen atmosphere. Reaction progress was monitored by thin layer chromatography, and upon completion solvents were removed under reduced pressure. The residue was purified directly using silica gel flash column chromatography (petroleum ether 60/40: acetone, 4:1) yielding 4 as a yellow solid $\left(0.13 \mathrm{~g}, 59 \%, \mathrm{R}_{f}=0.20\right)$. ATRFT IR $v_{\max } / \mathrm{cm}^{-1} ; 3503\left(v_{\mathrm{NH}}\right), 3407\left(v_{\mathrm{NH}}\right), 3104,2025\left(v_{\mathrm{CO}}\right), 1939\left(v_{\mathrm{CO}}\right), 1908\left(v_{\mathrm{CO}}\right), 1898\left(v_{\mathrm{CO}}\right)$, $1622\left(v_{\mathrm{C}=\mathrm{C}}\right), 1564\left(v_{\mathrm{C}=\mathrm{C}}\right), 1537\left(v_{\mathrm{C}=\mathrm{C}}\right), 1498,1292,1222,1036,806 .{ }^{1} \mathrm{H}$ NMR $\left(500 \mathrm{MHz}, d_{6^{-}}\right.$ acetone): $\delta 7.77(\mathrm{~s}, 1 \mathrm{H}), 7.65(\mathrm{~s}, 2 \mathrm{H}), 6.75(\mathrm{~s}, 2 \mathrm{H}), 5.41(\mathrm{~s}, 2 \mathrm{H}), 4.80(\mathrm{~s}, 2 \mathrm{H}), 3.82(\mathrm{bs}, 2 \mathrm{H}) .{ }^{13} \mathrm{C}$ NMR (125 MHz, $\mathrm{CDCl}_{3}$ ): $\delta 194.3$ (3x C $\left.\equiv \mathrm{O}\right), 149.9,130.4,127.6$ (2C), 119.4, 118.4, 115.2 (2C), 113.0, 84.1 (2C), 77.2 (2C). Anal. calcd for $\mathrm{C}_{16} \mathrm{H}_{11} \mathrm{ReN}_{4} \mathrm{O}_{3}$ : C, 38.94; H, 2.25; N, 11.35; Found: C, 39.02; H, 2.14; N, 11.19. HRMS (ASAP): $\left[\mathrm{C}_{16} \mathrm{H}_{11} \mathrm{ReN}_{4} \mathrm{O}_{3}+\mathrm{H}\right]^{+}$requires 495.0462; Found $495.0457[\mathrm{M}+\mathrm{H}]^{+}$. 
Supporting Information. ${ }^{1} \mathrm{H}-$ and ${ }^{13} \mathrm{C}-\mathrm{NMR}$, IR and UV-vis characterization data of compounds 2-4 is available to download as a separate file. CCDC 1002478 contains the supplementary crystallographic data for this paper. This data can be obtained free of charge from The Cambridge Crystallographic Data Centre via http://www.ccdc.cam.ac.uk/Community/Requestastructure/Pages/DataRequest.aspx

\section{Corresponding Author}

*Gregory G. Wildgoose; Email: G.Wildgoose@uea.ac.uk

\section{ACKNOWLEDGMENT}

The research leading to these results has received funding from the European Research Council

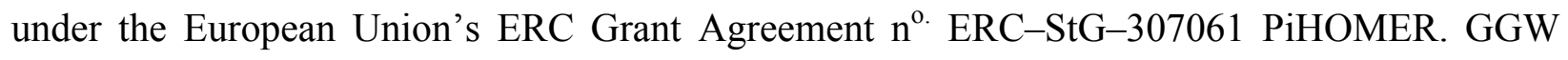
thanks the Royal Society for additional support via a University Research Fellowship. TD thanks the University of East Anglia for financial support via a Dean's studentship.

We wish to acknowledge the use of the EPSRC funded National Chemical Database Service hosted by the Royal Society of Chemistry.

We thank the EPSRC UK National Crystallography Service at the University of Southampton for the collection of the crystallographic data. ${ }^{30}$

\section{REFERENCES}

1 Recent reviews on half-sandwich organometallic complexes include: (a) Geiger, W. E. Organometallics, 2007, 26, 5738. (b) Geiger, W. E. Organometallics, 2011, 30, 28. (c) Geiger, W. E. Coordin. Chem. Rev., 2013, 257, 1459.

2 (a) To, T. T.; Duke III, C. B.; Junker, C. S.; O’Brien, C. M.; Ross II, C. R.; Barnes, C. E.; Webster, C. E.; Burkey, T. J. Organometallics, 2008, 27, 289. (b) Calladine, J. A.; Duckett, S. B.; George, M. W.; Matthews, S. L.; Perutz, R. N.; Torres, O.; Vuong, K. J. Am. Chem. Soc. 2011, 133, 2303. 
${ }^{3}$ Clough, M. C.; Zeits, P. D.; Bhuvanesh, N.; Gladysz, J. A. Organometallics, 2012, 31, 5231.

4 (a) Glans, L.; Hu, W.; Jöst, C.; de Kock, C.; Smith, P. J.; Haukka, M.; Bruhn, H.; Schatzschneider, U.; Nordlander, E. Dalton Trans., 2012, 41, 6443. (b) Dallagi, T.; Saidi, M.; Jaouen, G.; Top, S. Appl. Organometal. Chem., 2013, 27, 28.

${ }^{5}$ For publications indicating the radioactive nature of technetium; (a) Palm, C.; Fischer, E. O.; Baumgärtner, F. Naturwissenschaften., 1962, 49, 279. (b) De Jong, I. G.; Wiles, D. R. Inorganic Chemistry, 1976, 15, 2588.

${ }^{6}$ Young, R. D.; Hill, A. F.; Cavigliasso, G. E.; Stranger, R. Angew. Chem. Int. Ed., 2013, 52, 3699.

${ }^{7}$ Woys, A. M.; Mukherjee, S. S.; Skoff, D. R.; Moran, S. D.; Zanni, M. T. J. Phys. Chem. B., 2013, 117, 5009.

${ }^{8}$ Cautivo, T.; Klahn, H.; Godoy, F.; Lopéz, C.; Font-Bardía, M.; Calvet, T.; Gutierrez-Puebla, E.; Monge, A. Organometallics, 2011, 30, 5578.

${ }^{9}$ (a) Chong, D.; Laws, D. R.; Nafady, A.; Costa, P. J.; Rheingold, A. L.; Calhorda, M. J.; Geiger, W. E. J. Am. Chem. Soc., 2008, 130, 2962. (b) Wu, K.; Mukherjee, D.; Ellern, A.; Sadow, A. D.; Geiger, W. E. New J. Chem., 2011, 35, 2169.

${ }^{10}$ Geiger, W. E.; Barrière, F. Accounts Chem. Res., 2010, 43, 1030.

${ }^{11}$ Chong, D.; Stewart, M.; Geiger, W. E. J. Am. Chem. Soc., 2009, 131, 7968.

${ }^{12}$ Huisgen, R. in 1,3-Dipolar Cycloadditional Chemistry (Ed.: A.Padwa), Wiley, New York, 1984. 
${ }^{13}$ For comprehensive reviews on Click chemistry see; (a) Kolb, H. C.; Finn, M. G.; Sharpless, K. B. Angew. Chem. Int. Ed., 2001, 40, 2004. (b) ) Kolb, H. C.; Sharpless, K. B. Drug Discov. Today., 2003, 8, 1128. (c) Bock, V. D.; Hiemstra, H.; van Maarseveen, J. H. Eur. J. Org. Chem., 2006, 51. (d) Gil, M. V.; Arévalo, M. J.; López, Ó. Synthesis, 2007, 11, 1589. (e) Mirfeizi, L.; Campbell-Verduyn, L.; Dierckx, R. A.; Feringa, B. L.; Elsinga, P. H. Curr. Org. Chem., 2013, 17, 2108. (f) Xi, W.; Scott, T. F.; Kloxin, C. J.; Bowman, C. N. Adv. Funct. Mater., 2014, 24, 2572.

${ }^{14}$ (a) Kilpin, K. J.; Gavey, E. L.; McAdam, C. J.; Anderson, C. B.; Lind, S. J.; Keep, C. C.; Gordon, K. C.; Crowley, J. D. Inorg. Chem. 2011, 50, 6334. (b) Anderson, C. B.; Elliott, A. B. S.; McAdam, C. J.; Gordon, K. C.; Crowley, J. D. Organometallics, 2013, 32, 788.

${ }^{15}$ (a) Beyer, B.; Ulbricht, C.; Escudero, D.; Friebe, C.; Winter, A.; González, L.; Schubert, U. S. Organometallics, 2009, 28, 5478. (b) Happ, B.; Escudero, D.; Hager, M. D.; Friebe, C.; Winter, A.; Görls, H.; Altuntas, E.; González, L.; Schubert, U. S. J. Org. Chem. 2010, 75, 4025.

16 (a) Schweinfurth, D.; Weisser, F.; Bubrin, D.; Bogani, L.; Sarkar, B. Inorg. Chem. 2011, 50, 6114. (b) Schweinfurth, D.; Demeshko, S.; Khusniyarov, M. M.; Dechert, S.; Gurram, V.; Buchmeiser, M. R.; Meyer, F.; Sarkar, B. Inorg. Chem. 2012, 51, 7592. (c) Schweinfurth, D.; Krzystek, J.; Schapiro, I.; Demeshko, S.; Klein, J.; Telser, J.; Ozarowski, A.; Su, C.-Y.; Meyer, F.; Atanasov, M.; Nesse, F.; Sarkar, B. Inorg. Chem. 2013, 52, 6880.

${ }^{17}$ For articles reporting the modification of ferrocene with click chemistry for interesting applications; (a) Ornelas, C.; Aranzaes, J. R.; Cloutet, E.; Alves, S.; Astruc, D. Angew. Chem. Int. Ed. 2007, 46, 872. (b) Astruc, D.; Ornelas, C.; Aranzaes, J. R. Acc. Chem. Res. 2008, 41, 841. (c) Badèche, S.; Daran, J.-C.; Ruiz, J.; Astruc, D. Inorg. Chem. 2008, 47, 4903.

(d) Ornelas, C.; Aranzaes, J. R.; Salmon, L.; Astruc, D. Chem. Eur. J. 2008, 14, 50. (e) Romero, T.; Caballero, A.; Tárraga, A.; Molina, P. Org. Lett. 2009, 11, 3466. (f) Romero, T.; Orenes, R. 
A.; Espinosa, A.; Tárraga, A.; Molina, P. Inorg. Chem. 2011, 50, 8214. (g) Otón, F.; González, M. C.; Espinosa, A.; Ramírez de Arellano, C.; Tárraga, A.; Molina, P. J. Org. Chem. 2012, 77, 10083. (h) Otón, F.; González, M. C.; Espinosa, A.; Tárraga, A.; Molina, P. Organometallics 2012, 31, 2085. (i) Romero, T.; Orenes, R. A.; Tárraga, A.; Molina, P. Organometallics 2013, 32,5740 .

18 (a) Rapakousiou, A.; Wang, Y.; Belin, C.; Pinaud, N.; Ruiz, J.; Astruc, D. Inorg. Chem. 2013, 52, 6685. (b) Wang, Y.; Salmon, L.; Ruiz J.; Astruc, D. Nature Commun., 2014, 5, 3489.

19 Day, D. P.; Dann, T.; Hughes, D. L.; Oganesyan, V. S.; Steverding, D.; Wildgoose, G. G. Organometallics, 2014, DOI: 10.1021/om4007642

${ }^{20}$ Liu, Y.; Wang, X.; Xu, J.; Zhang, Q.; Zhao, Y.; Hu, Y. Tetrahedron, 2011, 67, 6294.

21 (a) Lunquist, R. T.; Cais, M. J. Org. Chem., 1962, 27, 1167. (b) Lage, M. L.; Curiel, D.; Fernández, I.; Mancheño, M. J.; Gómez-Gallego, M.; Molina, P.; Sierra, M. A. Organometallics, 2011, 30, 1794.

${ }^{22}$ Laws, D. R.; Chong, D.; Nash, K.; Rheingold, A. L.; Geiger, W. E. J. Am. Chem. Soc., 2008, $130,9859$.

${ }^{23}$ Yoo, E. J.; Ahlquist, M.; Kim, S. H.; Bae, I.; Fokin, V. V.; Sharpless, K. B.; Chang, S. Angew. Chem. Int. Ed. 2007, 46, 1730.

${ }^{24}$ Jaschinski, T.; Hiersemann, M. Org. Lett. 2012, 14, 4114.

${ }^{25}$ Dolomanov, O. V.; Bourhis, L. J.; Gildea, R. J.; Howard, J. A. K.; Puschmann, H. J. Appl. Cryst., 2009, 42, 339. 
${ }^{26}$ (a) Palatinus, L.; Chapuis, G. J. Appl. Cryst., 2007, 40, 786.; (b) Palatinus, L.; Prathapab, S. J.; van Smaalen, S. J. Appl. Cryst., 2012, 45, 575.

${ }^{27}$ (a) Sheldrick, G. M. http://shelx.uni-ac.gwdg.de/SHELX/; (b) Sheldrick, G. M. Acta Cryst., 2008, $A 64,112$.

${ }^{28}$ Gritzner, G.; Kůta, J. Electrochim. Acta. 1984, 29, 869.

${ }^{29}$ Lawrence, E. J.; Oganesyan, V. S.; Wildgoose, G. G.; Ashley, A. E. Dalton Trans. 2012, 42, 782 For other leading references; S. Lancaster, ChemSpider SyntheticPages, 2001, http://cssp.chemspider.com/215 DOI:10.1039/SP215; T. E. Krattf (inventor), Boulder Scientific Company (assignee), European patent 1,186,608, 2002 Mar 13; LeSuer, R. J.; Buttolph, C.; Geiger, W. E. Anal. Chem., 2004, 76, 6395.

${ }^{30}$ Coles, S. J.; Gale, P. A. Chem. Sci., 2012, 3, 683. 